\title{
MONEY ATTITUDES VS ECONOMIC SOCIALIZATION IN POLAND
}

\author{
Aneta KOWALCZYK, Joanna CHUDZIAN*
}

Address:

Warsaw University of Life Sciences, Faculty of Economic Sciences, Department of European Policy, Public Finance and Marketing, Division of Marketing and Market Analyses, Nowoursynowska Str, 166, 02-787 Warsaw, Poland

*Corresponding author, e-mail: joanna_chudzian@sggw.pl

\section{ABSTRACT}

This article concerns the attitudes people have towards money, analysed from an economic and psychological point of view. The article presents an overview of current knowledge on the issues of money attitudes, as well as derived own research derived. This research was designed in order to identify different types of money attitudes as well as their determinants. The study identified five dominant profiles and showed that the most popular is a rational approach, and second - it's opposite - improvidence. The results have been faced with the most important economic socialization determinants identified during the literature review. The comparison proved to be important, e.g. in the form of receiving pocket money.

Keywords: attitude, material values, personality, economic socialization, financial psychology JEL: D12, D14, G02

\section{INTRODUCTION}

Economic sciences deal with the study of choices individuals make in situations of different and limited resources in order to achieve the intended purpose (Dijkstra and Plantega, 2003). These individuals make these choices based on their own personal hierarchies of values towards which they exhibit specific attitudes. In economic science, the researchers focus on the determinants of rational decisions. In turn, economic psychology researchers focus on the perception of money and the determinants shaping money attitude (Zaleśkiewicz, 2011). The essence of money for every man is a combination of economic and psychological aspects, since any economic behaviour is conditioned by both internal factors of human and economic socialization (Wąsowicz-Kirylo, 2008). Such an approach to the money spending is a starting point for this article.

Economic socialization is an aspect of social development of an individual. This kind of socialization has integral parts or subcomponents such as consumer socialization and financial socialization (Alhabeeb, 2001). Study conducted by Jorgensen and Savla (2010) has shown that a lot of young adults have inadequate financial attitudes and knowledge. Therefore, it is necessary to consider that economic socialization is very important, because knowledge is not influenced by only developmental changes in cognitive functions but also by experiences, which are related with specific economic conditions under which the child grows up (Wosiński, Pietras, 1990).

In the literature (e.g. Wilson, 1999) it is considered that the first researcher who undertook to describe the diversity of people's attitudes towards money was Otto Fenichel, who developed the concept of
Freud's psychoanalytic approach to present the individual differences occurring in the attitudes towards money. He believed that - in terms of money attitudes - people are focused on retention (possessions for themselves) or expulsion (satisfaction with excessive money spending). On the other hand, according to Hostyński (2006) who dealt with money through the lens of consumption and axiology, money as a symbol of the material value has a twofold meaning:

- It can be a value in itself, even though such situations are rather rare.

- It can be regarded as a tool that allows for measuring the value of goods.

Money attitude is defined in the literature as an entirety of relatively stable tendencies to evaluate money and emotionally respond to them and relatively stable accompanying tendencies to the certain kind of behaviour associated with money (Gąsiorowska, 2009).

One of the first attempts to examine money attitudes was made by Rubinstein (1981), who published a questionnaire, which examined respondents' attitudes towards money taking into account the relationship to spending and saving money as well as perception of own financial situation. Earlier, researchers such as Wernimont and Fitzpatrick (1972) studied the importance of money on groups of adult consumers. The researchers recognize multiple dimensions of money attitudes that depend on the adopted criteria. The most interesting dimensions in this area were presented by Templer and Yamauchi (1982) and Furnham (1984). Due to the objective of the empirical part of this article, it was decided to present the dimensions of money attitudes as suggested by Furnham. These are:

- Obsessions: a strong focus on money, treating money as the only thing to rely on. 
- Force / Spending: money - a means of exerting an impression on others, money can "buy" friendship.

- Abstaining: avoiding spending money, even in a situation of having a sufficient quantity of money,

- Security / Conservatism: devoting much attention to financial matters, control.

- Maladjustment: degree of satisfaction with the level of wealth and owned savings.

- Effort / Ability: rating ability to influence own financial situation.

The listed dimensions indicate areas that determine individual attitudes toward money. As it is well known, people have different money attitudes; they assign them a different meaning in their lives, which is manifested in different aspects - dimensions.

Question of money attitudes was explored and described by many Polish researchers, to name only Górniak (2000), Bajcar and Gąsiorowska (2004) and Wąsowicz-Kirylo et al. (2005). When Bajcar and Gąsiorowska were considering money attitudes they drew attention to the different understandings of money by people and they took into account seven dimensions:

- Financial control - the degree of control in making financial decisions.

- Power resulting from the money - money is considered a tool to influence/impress.

- Anxiety about finances - concerns the degree of doubt, determination on all matters related to finance.

- Aversion to financial obligations - related to the degree of aversion to make these commitments and their fulfilment.

- Catching the opportunities - associated with a tendency to exploit financial opportunities.

- Poor money - refers to a negative attitude towards money resulting from a belief that they are something captivating, bad.

- Real cash - attitude towards cash and other forms of money.

Based on the considered dimensions of money attitudes literature presents many personality types related to money (types of attitudes towards money). The most interesting were presented by Poduška (1993), Price (2000), Gurney (1988) and Mellan (1994). Of these, the greatest attention should be paid to the types described by Deborah Price. She singled out eight types of people with different attitude to money.

The types of money attitudes distinguished by Price are closely associated with the personality of a person, its general features. According to the assumptions of the author assignment of financial personality occurs choosing the adjectives (out of 69) that describe the subjective perception of a person (Wąsowicz-Kirylo, 2008).

On the other hand, the study by Mellan (1994) has the most practical use as the typology of money attitudes. Based on the cases collected in the course of clinical work and research she singled out five personality types of financial personalities:
- Hoarders - money is a safety condition for them; they meticulously plan and control spending, saving money, collecting money for a "rainy day". They do not purchase on impulse. Such people do not like to spend money, but they are happy to deal with their budget.

- Spenders - money is central for these people, serving different purposes, one of them - a particularly important - is simply a pleasure. These people willingly spend money spontaneously, they cannot and do not like to save money.

- Money monks - they think that money is dirty and is a source of evil. They do not want to collect it, and even think that it is harmful, because it can lead to depravity. For these people, money is unimportant detail in life, but at the same time they believe it is a way to help other people and improve the world.

- Money Avoiders - they are afraid of money, do not like and do not know how to deal with financial matters, therefore they try to avoid making financial decisions. They even cannot do the simplest formalities relating to money.

- Money amassers - they love to collect and spend money, they behave like a seasoned managers of their own resources, pay a lot of attention to money. These individuals demonstrate a high level of financial competence, but they tend to judge themselves and others through the lens of money.

Mellan, like Price, says that the ability to deal with money involves understanding oneself and adapting financial behaviour to psychological characteristics. Mellan's typology, based on questionnaire research, indicates that we rarely deal with the representation of strictly one type of personality. Simultaneously, Mellan's typology seems to be more practical in use and is easier to operationalize, usually due to the smaller number of individual types of personalities. In addition, it is more intuitive typology, through the use of specific statements on a Likert scale rather than a comprehensive set of individual adjectives, as it is the case of Price's method. Therefore, in the course of work on the empirical part of this article to build a proprietary questionnaire there were used key personality types distinguished by Mellan but taking into account the Polish test conditions.

From the point of view of research conducted over the distribution of money, the relevant question is not merely the existence of different types of money attitudes, but also identification of the determinants of these attitudes. Researches mentioned above were rather focused on psychological aspects - separating different types of attitudes towards money. The research carried out for empirical part of this article - due to determinants considered - carries also economic implications. Studies by psychologists suggest that the list of factors that determine money attitudes is fairly comprehensive (Wąsowicz-Kirylo, 2008). Knowledge of the factors influencing the types of attitudes can help shape the "economically desirable" attitude and development of 
this attitude mainly affects the economic socialization. Waliszewski (2010) claims, that the financial education and economic knowledge of household members plays a crucial role in the effective management of personal finances. Consequently, these elements lead to lifelong financial awareness. Waliszewski recognizes the financial education as a process of building financial and economic education and also as a process of economic competence building by people. Researchers point the importance of early financial experiences of young people in the family home (Gurney, 1988). Mellan ensures that family patterns may be adopted or denied, leading to the formation of inverse behaviour (Mellan, 1994). However, as indicated earlier, consciously pursued economic socialization should not be understated.

Tyszka (2004) states, that this socialization covers acquisition of knowledge, skills and behaviours, creating opinions, attitudes and representations regarding the world economy. In Waliszewski's opinion (2010) the acquisition of economic and financial knowledge should be done systematically by introducing respective subjects in the curricula of primary schools, middle schools, high schools and finally in college. He also claims that a person educated in the current system is "socially handicapped", because without a proper economic knowledge he allows other person manipulate him. It should be noted that elements of this kind of socialization are e.g. school activities on economic issues or organization of variety of projects relating to the issue, such as class budgets (Wąsowicz-Kirylo, 2008).

In addition to the economic socialization, money attitudes are also influenced by demographic factors. For example, the western researches (Wąsowicz-Kirylo, 2008) pointed to gender differences in the perception of money. According to these results, money for women has rather a symbolic meaning, being a basis for a sense of security or as symbol of the prestige. Similarly, age was diagnosed as a determinant of attitudes towards money. It was found that older people experience greater anxiety associated with issues of money and to a lesser extent assign the symbolism of power or success. In addition, it was found that with higher education comes a better ability to refrain from spending money (Roberts and Sepulveda, 1999). Tang (1992) found that people with higher incomes are likely to evaluate the money as a good thing, a proof of the successes.

Presented state of research on money attitudes indicates that there are differences between people in terms of perception and in evaluation of material values. The most important however, is that these differences can be explained by specific factors that influence attitudes towards these values. It is important also that these factors are variable in time and across different groups of people. They are also culturally diverse. Therefore, the research problem of this article is the relationship of the individual, characterized by certain regularities, types of money attitudes across adult Poles and the factors that shape those types. The hypothesis, which was applied in this study, is that adult Poles exhibit certain types of money attitudes and that it is possible to identify factors which shapes these attitudes.

One possible use of this research is the implications arising from the awareness of the existence and operation of specific factors affecting attitudes towards material values. This article may provide a boost to help realize that currently often ignored issue of the existence of shaped money attitudes is often a source of social as well as economic problems.

\section{MATERIAL AND METHODS}

The method of research used for the purpose of this study was a diagnostic survey method and technique - a questionnaire. Geographical area of research, aimed at young adults (students), was Masovian Voivodeship in Poland. The nationality of respondents gave the possibility to explore the topic on the group of one of the most non-educated in the field of economy group in EU. As Poland is one of the biggest population within new EU members, it seems to be very interesting to start research this topic from that group. The sample was chosen deliberately as 100 adults. We have made sure that the respondents, who study in Warsaw, come from different places, both rural and urban. An important to note is that among respondents, one-half were graduates or students of economical faculties, while the other half are representatives of uneconomical fields.

The research tool was a questionnaire. It was built in two parts. One of the blocks concerned money attitudes and has been constructed so that it was possible to identify the type of respondent's money attitude. The second block was a reference to the factors that may be responsible for shaping the attitude. During the study, five types of money attitudes were isolated across the respondents:

- Rationalists - they approach with caution to financial matters,

- Wasteful - they don't recognize the concept of saving, and money is a means to achieving the happiness,

- Money lovers - they strive for wealth, value accumulation and spending funds,

- Non-materialists - they do not endeavour to achieve wealth - money is only a means of achieving higher purpose objectives,

- Passive - they are absolutely not involved in any financial issues.

Assigning a person to a particular type of attitude was based on individual adaptation to specific statements, which are typical for particular types of attitudes. For example, such statements characterize "rationalists": "Money gives me a sense of security" or "I do not make purchases on impulse". In turn the "wasteful” were classified based on positive responses to statements such as: "Money is a means of satisfying desires" or "Saving is not important for me". "Money lovers" chose such statements: "I often pay attention to the economic status of others" or "I feel better, when I have some money". Group of "Non-materialists" was characterized by a positive attitude to statements such as: 
"Money corrupts man" or "Money can be an instrument to help improve the world". A group of "Passive" chose the following statements: "I keep away from financial issues" or "Finance and management are not my strong points”.

\section{Characteristics of the study population}

In order to learn the demographic structure of the sample, respondents were asked a series of questions that helped to determine the demographic profile (Table 1), and in addition were included elements of socialization, which could have an impact on the process of shaping money attitudes (Table 2). Type of faculty was considered an indicator of purposeful selection of the research group. As mentioned before, graduates or students of economical courses constitute $50 \%$ of the sample, other $50 \%$ - faculties not related to economy.

Table 1 Structure of the respondents according to set of independent variables - demographic

\begin{tabular}{llr}
\hline Variable & Category & Percentage (\%) \\
\hline \multirow{2}{*}{ Sex } & women & 77 \\
Age & men & 23 \\
& $19-22$ & 36 \\
& above 23 & 64 \\
Resident-origin & big city & 27 \\
& small town & 22 \\
Type of education & village & 51 \\
& economical & 50 \\
& uneconomical & 50 \\
Mother's education & basic & 4 \\
& vocational & 22 \\
& medium & 46 \\
\multirow{2}{*}{ Father's education } & higher & 28 \\
& basic & 6 \\
& vocational & 39 \\
& medium & 34 \\
Number of siblings & higher & 21 \\
& from 1 to 2 & 10 \\
& above 3 & 74 \\
Source: Own survey & & 16 \\
\hline & &
\end{tabular}

In summary, factors characterizing each respondent were adopted as independent variables. These factors may affect the formation of particular money attitude in an individual case, and these are respectively: sex, age, current place of residence, education, field of study, parents' education, number of siblings, financial situation of the family in which a person grew up, the attention paid to issues of finance by parents, commitment to family finances in individual's youth, use of banking products (during adolescence), receiving pocket money in the past, participation in school activities on economic issues, participation in educational programs on economic issues or watching economic programs.

\section{RESULTS AND DISCUSSION}

In the empirical research the dependent variable was money attitude allocated by the questionnaire, which was described earlier in the article. People have been assigned to individual respondents' attitudes towards money, based on the prevailing opinion in the questionnaire. The procedure is described in the part of article, which name is "Material and methods". The classification of respondents in each group has been determined on the basis of the modal value. As has already been indicated, it is not always possible to clearly identify one type of money attitude, as a single characteristic of a person. Therefore, the study recognized more than one dominant money attitude in some cases. Based on the research, a structure of the number of common types of money attitudes was separated (Table 3).

Table 2 Structure of the respondents according to set of independent variables - socio-economical

\begin{tabular}{llr}
\hline Variable & Category & $\begin{array}{r}\text { Percentage } \\
\text { (\%) }\end{array}$ \\
\hline Person supporting the & one of the & 32 \\
family & parents & \\
& both parents \\
Financial situation & very good & 68 \\
& satisfactory & 18 \\
& unsatisfactory & 69 \\
Strong attention paid to & definitely yes & 13 \\
finance & difficult to say & 28 \\
& probably not & 68 \\
Parents talk about finance & very often & 4 \\
& sometimes & 18 \\
& never & 79 \\
Commitment to family & yes & 3 \\
finances & no & 37 \\
Use of banking products & yes & 63 \\
(during adolescence) & no & 31 \\
Receiving pocket money & regularly & 69 \\
in the past & occasionally & 33 \\
& never & 58 \\
Participation in school & yes & 9 \\
activities & no & 56 \\
on economic issues & & 44 \\
Participation in & yes & \\
educational & no & 26 \\
programs on economic & & 74 \\
issues & & \\
Watching economic & often \\
programs & occasionally & \\
& never & \\
\hline Source: Own surve. & & \\
& & \\
& & \\
& & \\
& &
\end{tabular}

Source: Own survey.

Table 3 Structure of the number of types of money attitudes, found in the research sample

\begin{tabular}{lr}
\hline Number presented attitudes & Percentage (\%) \\
\hline 1 dominant attitude & 85 \\
2 dominant attitudes & 12 \\
3 or 4 dominant attitudes & 3 \\
Sum & 100 \\
\hline
\end{tabular}

Source: Own survey.

According to the presented data, $85 \%$ of respondents presents only one type of attitude, $12 \%$ are characterized by two dominant attitudes. We can therefore conclude that the money attitudes presented in the study are different enough to allow for further intercomparison. To simplify the analysis, only persons, who 
presented only one type of attitudes, have been tested in further study. These cases have the greatest educational value.

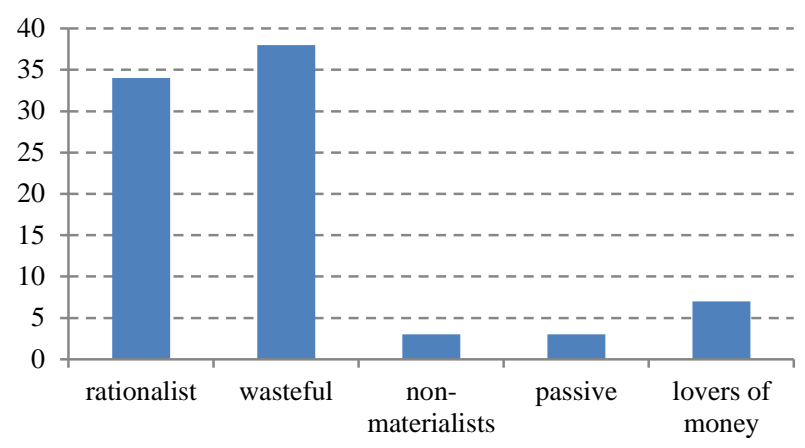

Number of respondents

Figure 1 Number of respondents with different types of money attitudes

Source: Own survey.
The bulk of the respondents reveal the specific characteristics of the two types of money attitudes rational or wasteful (Fig. 1). It is worth noting that these are antagonistic groups. At the same time it should be added that a relationship of demographic variables and socialization with the presented types of money attitudes was also observed. Table 4 and Table 5 present detailed profiles of the two most common types of financial personality: rationalists and wasteful. These tables take into account what share of respondents belonging to a group by various independent variables, such as age of a person, presents particular attitude.

Women more often have specific characteristics typical for "wasteful", more rarely for "rationalist". On the other hand greater number of men - reveal "rationalist's" characteristic. This has been confirmed in studies by other researchers, according to which women usually worse evaluate their competence in the field of finance, more rarely invest, and also are more likely to experience feelings of guilt in relation to spending money (Kaczmarek, 2005).

Table 4 Economic socialization profile of rationalists

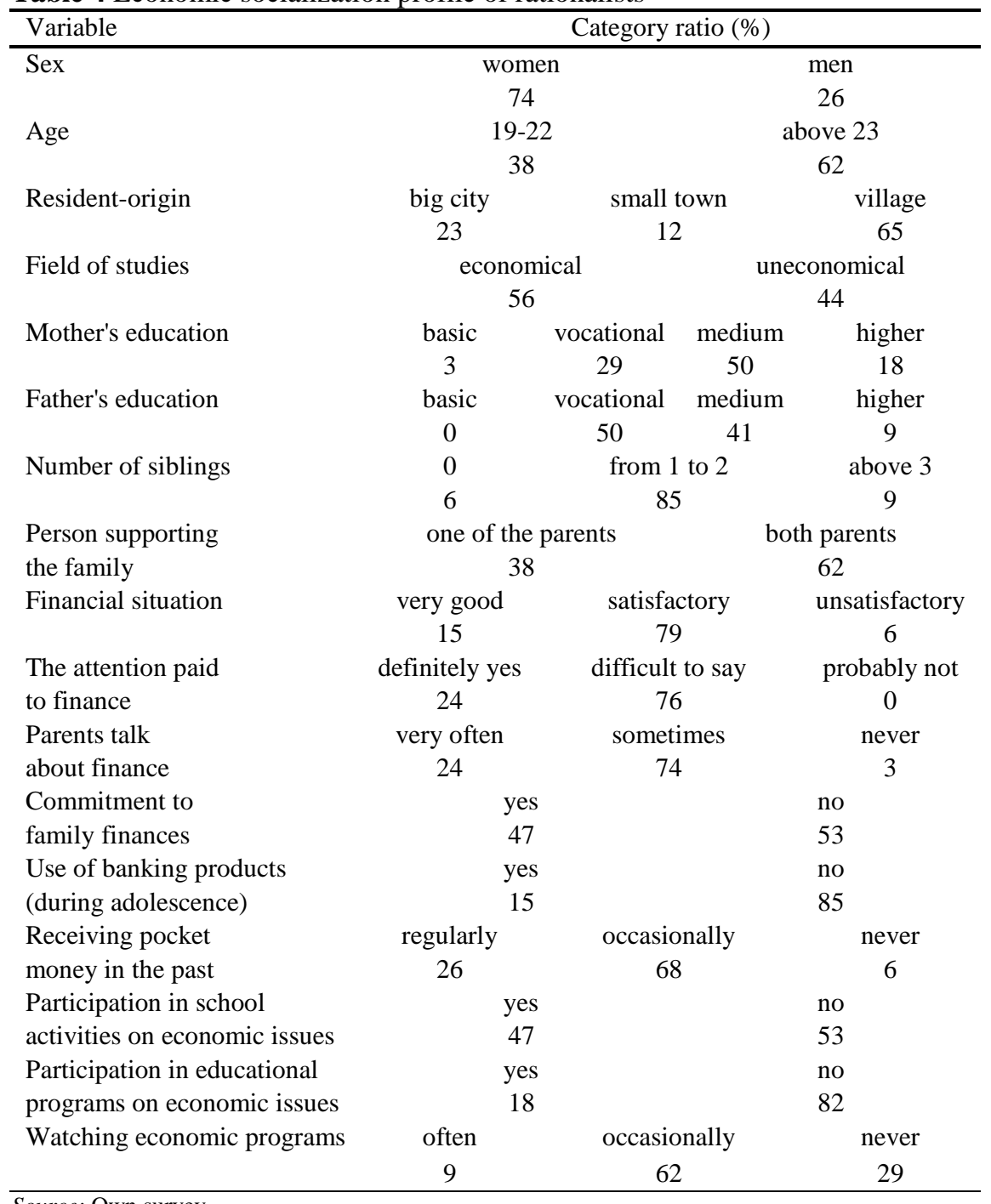

Source: Own survey. 
Table 5 Economic socialization profile of wasteful

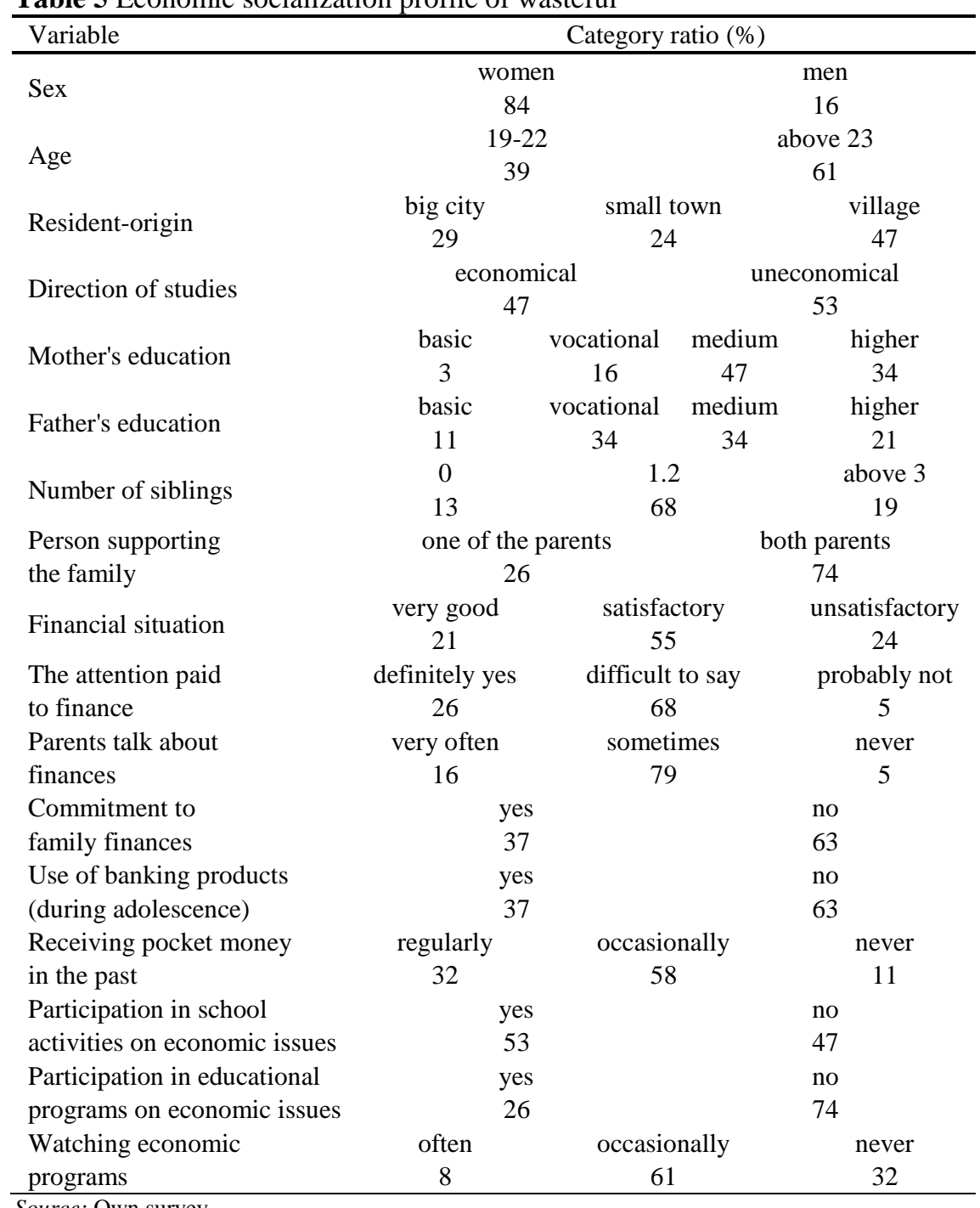

Source: Own survey.

It was also found that in case of respondents from both, large and small cities, more common type of money attitude was a type of "wasteful”. In case of the rural population, more popular in this group was type of "rationalist".

The research shows that larger part of students of economical fields has qualities appropriate for a "rationalists" 56\% of this group, while for uneconomical courses there are only $44 \%$. In this group, the predominant type was a type of "wasteful" (53\%), which in the case of "economical" students was equivalent to $47 \%$ of the group. The fact that economic socialization has a significant impact on the behaviour of financial rationality was also confirmed by observations of other researchers (Waliszewski, 2010).

People growing up in families with very good financial situation more often exhibit specific characteristics of the type of "wasteful" $21 \%$ of this group, when in case of "rational" (15\%). In turn, a significant part of respondents, whose family financial situation was unsatisfactory, has characteristics of "wasteful" (24\%), while characteristics of "rationalists"' only $6 \%$. This was confirmed by the tests, which were conducted by authors such as Roberts and Sepulveda (1999). According to their results in case of higher income there is also a higher motivation to save money than among those who experience worse financial situation.

Persons, whose parents did not use to pay attention to the most common financial issues, there is more often "wasteful" type (5\%) than "rationalists" (0\%). This obviously relates to economic socialized, its existence led to a more prudent approach to financial matters. Research results of Dutch young adults have shown positive links between parental encouragement and for example ability to control spending (Webley and Nyhus, 2013).

People whose parents often talked with them about finance frequently represent the greater part of "rationalists" (24\%) than of "wasteful" (16\%). Similarly, individuals who were involved in these issues, are $47 \%$ of "rationalists", "wasteful" 37\%. It confirms the thesis of Wąsowicz-Kirylo (2008), according to which the attention paid to money shown by the parents, as well as their ways of coping with financial matters, play a 
significant role in how their children find their way in the world of finance.

Considering received pocket money from among "rationalists" 6\% didn't receive this kind of money, and $11 \%$ from among "wasteful" type. This suggests that people, who have had no contact with an economic socialization in the form of pocket money, think less serious about financial issues. Namely, children who had their own money better deal in financial problems in their adulthood (Lea et al., 1987).

According to the results of the research, individuals who in their youthful age benefited from banking products, are the more consistent with the characteristics of a person "wasteful" it is about 37\%, less frequently with "rationalists" $15 \%$. This situation can be explained by the fact that people who used to use banking products, treat them only as a tool on the way to fulfilling their "whims" without understanding their essence.

\section{CONCLUSION}

The main purpose of the article was showing the existence of differences between people in terms of attitudes towards material values, and more importantly, that these differences can be reasonably explained by specific factors. The purpose of this was also to indicate that among these factors there are those that can't be shaped - e.g., gender or age, but also those, can be controlled during the process of socialization - such as the involvement by parents in family finances issues, etc.

Factors which were supposed to influence the process of shaping the attitudes towards material values, indeed showed a significant effect on the shaping of these attitudes in most cases. The study conducted had its limitations, such as the participation of mainly young people - students, which did not allow for the efficient differentiation of types of attitudes according to the criterion of age.

Identification of the types of money attitudes has its far-reaching economic implications. The existence of differences of money attitudes or financial personalities has its application in the world of consumption. Awareness of these differences is essential to carry out the marketing segmentation, which is now the basis for the action of all kinds of enterprises, which are, in turn, the base of the whole economy.

In addition to marketing segmentation, money attitudes are used in case of financial advisory services. The determination of the characteristics, which influence the way that individuals manage their money, are the basis for the functioning of financial advisory services. As pointed out by Wąsowicz-Kiryło (2008), identification of theses characteristics allows for working out more efficient ways of managing money, which lead to an increase in the level of satisfaction with selfactivity as well as improvement of the financial situation. Studies indicate that on the other hand an unsuccessful economic socialization can cause many microeconomic and macroeconomic problems (Zaleśkiewicz, 2011).
This article is expected to provide an impulse that will help to realize that the issue of the existence of shaped money attitudes is often a source of social, as well as economic problems.

\section{REFERENCES}

ALHABEEB M.J. 2001. On the economic socialization of youth, Proceedings of the Academy of Marketing Studies, Volume 6, Number 1.

BAJCAR, B. - GĄSIOROWSKA A. 2004. Poznawcze i temperamentalne uwarunkowania postaw wobec pieniędzy, (in:) Sukces w zarządzaniu kadrami. Perspektywa globalna i lokalna, pod red. T. Listwan, Wrocław.

DIJKSTRA A. G. - PLANTEGA J. 2003, Ekonomia i płeć, Gdańskie Wydawnictwo Psychologiczne, Gdańsk, FURNHAM, A. (1984). Many sides to the coin: The Psychology of Money Usage, Personality and Individual Differences, 5(5), 501509. http://dx.doi.org/10.1016/0191-8869(84)90025-4

GĄSIOROWSKA A. 2009. Różnice indywidualne jako determinanty postaw wobec pieniędzy, Unpublished PhD thesis available in Library of University of Wrocław. Warszawa.

GÓRNIAK, J. 2000. My i nasze pieniądze. Aureus. Kraków.

GURNEY, K. 1988. Your money personality, Financial Psychology Corporation.

HOSTYŃSKI L. 2006. Wartości w świecie konsumpcji, Lublin. Wydawnictwo UMCS. Lublin.

JORGENSEN, B.L. SALVA, J., Financial Literacy of Young Adults: The Importance of Parental Socialization, Family Relations; Oct 2010; 59, 4; ProQuest, 465-478. http://dx.doi.org/10.1111/j.1741-3729.2010.00616.x LEA, S. E. G., TARPY R. M., WEBLEY P. 1987. The individual in the economy, Cambridge University Press, Cambridge.

MELLAN, O. 1994. Money Harmony, Walker, New York.

PODUSKA, B. 1993. For love and money, Pacific Grove, CA: Brooks/Cole.

PRICE, D. L. 2000. Money therapy, Using the eight money types to create wealth and prosperity. New World Library. Novato, California.

ROBERTS, J. A. - SEPULVEDA C. J. M. 1999. Demographics and money attitudes: A test of Yamauchi and Templer's (1982) money attitudes scale in Mexico, Personality and Individual Differences, 27, 1935. http://dx.doi.org/10.1016/s0191-8869(98)00241-4

TANG T. L. P. 1992. The meaning of money revisited. Journal of Organizational Behaviour, 13, 197-202. http://dx.doi.org/10.1002/job.4030130209

TYSZKA, T. (red.) 2004. Psychologia ekonomiczna. Gdańskie Wydawnictwo Psychologiczne, Gdańsk.

WALISZEWSKI, K. 2010. Doradztwo finansowe w Polsce. Wydawnictwo CeDeWu, Warszawa.

WĄSOWICZ-KIRYŁO, G. 2008. Psychologia finansowa: o pieniądzach w życiu człowieka. Wydawnictwo Difin, Warszawa, 
WEBLEY, P. - NYHUS, E.K. 2013. Economic socialization, saving and assets in European young adults, Economics of Education Review, April 2013, vol. 33, p. 19 -

30. http://dx.doi.org/10.1016/j.econedurev.2012.09.001 WERNIMONT, P. F., FITZPATRICK, S. 1972. The meaning of money, Journal of Applied Psychology, 56, 218-226. http://dx.doi.org/10.1037/h0033107

WILSON, V. 1999. The Secret Life of Money: Exposing the Private Parts of Personal Money. N.S.W.: Allen \&Unwin. St. Leonards.
WOSIŃSKI, M., PIETRAS, M., 1990, Economic Socialization of Polish Children in Different MacroEconomic Conditions, Journal of Economic Psychology 11.4, 515-528.

http://dx.doi.org/10.1037/t26591-000

YAMAUCHI, K., TEMPLER, D. 1982. The development of a money attitudes scale, Journal of Personality Assessment, 46, 522-528.

http://dx.doi.org/10.1207/s15327752jpa4605_14

ZALEŚKIEWICZ, T. 2011. Psychologia ekonomiczna. Wydawnictwo Naukowe PWN, Warszawa 